Annals of Plant Sciences

ISSN: 2287-688X

OPEN ACCESS

Research Article

www.annalsofplantsciences.com

\title{
Foliar micromorphological character studies on Trichosanthes L. (Cucurbitaceae) from Terai \& Duars, West Bengal, India.
}

Roshni Chowdhury ${ }^{1}$, Anurag Chowdhury ${ }^{2} \&$ Monoranjan Chowdhury ${ }^{1 *}$

${ }_{1}$ Plant Taxonomy \& Biosystematics Laboratory, Department of Botany, University of North Bengal, Darjeeling, India. ${ }^{2}$ ACF, Central Academy for State Forest Services (CASFOS), Burnihat, 793101, Assam, India.

Received: 05-09-2018; Revised: 17-09-2018; Accepted: 28-09-2018

\begin{abstract}
Trichosanthes is one of the most economically important genera of the family Cucurbitaceae. Studies on trichome micro-morphology and stomata were investigated for six species of Trichosanthes. All species has been recorded from the Terai and Duars of West Bengal. Range of variability in Trichosanthes species are quite variable, trichomes types including uni-multiseriate, macro-microform, conical, candelabra, capitated, glandular and nonglandular. Stomatal character shows variability (Paracytic, Actinocytic, Anomocytic and Diacytic). Trichomes and stomatal characters are utilised for phenetic studies which found to be important taxonomic tools to solve any disputes at least at or below species level.
\end{abstract}

Keywords: Stomata; Taxonomic significance; Trichosanthes; Trichomes; Cluster analysis

\section{Introduction}

Lamina being important part of plant acquire a good number of anatomical and micromorphological features that are most varied in angiosperms. Though these can be employed as needful taxonomic delimitations (Metcalfe 1968). Foliar micro-morphological characters, especially the trichomes and stomata are considered as some of the primary diagnostic features in segregating the major groups of plants and epidermal characters are used successfully in the delimitation of a number of taxa (Chauhan and Daniel, 2011). Different types of glandular and non-glandular trichomes are important diagnostic features of members of Cucurbitaceae and around more than 300 descriptions of trichome types are recorded in different botanical literatures (Kolb and Müller, 2004). The elaborate study on structure and distribution pattern of trichomes among the different genus of Cucurbitaceae have received considerable attention of various earlier workers (Inamdar et al., 1990, Ibrahim 2003, Kolb and Muller 2004, Inamdar and Gangadhara 2008, Ali and Fahad 2011, Abdulrahaman et al., 2011, Adebooye et al., 2012, Bibi and Okoli 2014). Trichosanthes Linnaeus, (Sp. Pl. 2:1008.1753) is the most interesting and economically valuable genera of Cucurbitaceae. The fruits, flowers and tender shoots of Trichosanthes dioica and Trichosanthes cucumerina are quite popular vegetables in India especially in North East India. For this genus 206 scientific names are available, of which 37 are accepted species along with 14 scientific plant names of infraspecific rank (theplantlist.org.). Mitra et al., (2005), reported around 22 species of Trichosanthes from territory of India and out of that
10 species from West Bengal. 21 species are mostly concentrated to the Malabar Coast in WesternGhats and North-Eastern region of India (Rai et al., 2008). Study of overall foliar micro-morphological character of this genus is variable among the species level. The trichomes and stomatal characters and their comparative analysis for the genus Trichosanthes is less explored. Hence, the present communication deals with micro-morphology of six species of Trichosanthes of Cucurbitaceae, quite common in wild and cultivated in Terai and Duars parts of West Bengal, India.

\section{Materials and Methods}

To study the variation of foliar epidermal micro morphology of six species of Trichosanthes [T. lepiniana Mohitnagar, 012, dated 12.05.2016; T. tricuspidata Sukna, 021, dated 25.05.2016; T. quinquangulata Haldibari, 019, dated 20.05.2016; T. dioica Mandalghat, 013, dated 12.05.2016; $T$. cucumerina Dhabganj, 020, dated 20.05.2016; $T$. wallichiana Kurseong, 025, dated 25.05.2016] microscopic anatomical observations were carried out following the standard method (Metcalfe, 1950; Esau, 1959 and Creedy, 1977). Fresh and fertile specimens of Trichosanthes sp. were collected from different habitats of the study area. About $2.5 \mathrm{~cm}$ long foliar parts were taken peeled from both epidermal surfaces and then mounted. Camera Lucida drawings were done and measurements of the stomata, guard cells and trichomes were recorded under standardized ocular micrometre. The photographs were taken under the Magnus microscope and Leica DM LS 2 microscope with 10 $\mathrm{X} \& 40 \mathrm{X}$ objectives. For studying trichomes

\section{${ }^{*}$ Corresponding Author:}

Dr. Monoranjan Chowdhury,

Assistant Professor, Plant Taxonomy \& Biosystematics Laboratory,

Department of Botany, University of North Bengal,

Darjeeling, 734013, West Bengal, India.

E-mail: mono_malda@yahoo.co.in 
epidermal peels were taken out manually using blade and forceps by scrapping method and for stomatal studies maceration of cuticles in conc. nitric acid were done. Finally, the specimens were rinsed in distilled water, stained with $1 \%$ aqueous safranin solution and mounted in 5\% glycerine. Different Stomatal parameters including stomatal type, stomatal frequency, stomatal index and stomatal size (Dilcher, 1974) and frequency of each complex type were expressed as percentage occurrence of such complex type based on all occurrences (Obiremi \& Oladele, 2001). Epidermal cell size was determined as product of length and breadth (Philips, 1959). All the voucher specimens were deposited at NBU Herbarium. For Hierarchical cluster analysis XLSTAT 2014.5.03 software is used. Similarity is weighed based on Pearson's Correlation Coefficient.

\section{Results}

Foliar Micro-morphological evidences in the six species of the genus Trichosanthes seems to be enough diagnostic values for delimiting species studied. The foliar micro-morphological features were analysed by its qualitative and quantitative characters. Detailed variable shapes, size of trichomes and stomata for all the collected species of Trichosanthes examined carefully. Four types of stomata's were recorded Anomocytic ( $T$. quinquangulata, $T$. dioica, male), Actinocytic ( $T$. tricuspidata), Paracytic (T. lepiniana \& T. dioica, female) and Diacytic (T. cucumerina \& T. wallichiana).In $T$. lepiniana, $T$. cucumerina and $T$. wallichiana, $T$. dioica (male) stomata present only in abaxial surface. Whereas, in T. tricuspidata, T. quinquangulata, T. dioica (Female) stomata are present on both surfaces. Quantitative Stomatal characters are important tool for determining taxonomic significance. Therefore, largest stomata are found in T. dioica female 13 O.D whereas smallest in T. cucumerina 5 O.D. The range of stomatal index was varying from $26.6 \%$ in Trichosanthes quinquangulata to $9.52 \%$ in Trichosanthes cucumerina. All the specimens comprise of nonglandular hair except female $T$. dioica.

Table 1. Stomatal and trichome parameters of Trichosanthes sp. (Vernacular names B: Bengali, E: English, H: Hindi)

\begin{tabular}{|c|c|c|c|c|c|c|}
\hline Taxa & $\begin{array}{c}\text { Stomatal } \\
\text { Frequency }(\mu \mathrm{m})\end{array}$ & $\begin{array}{r}\text { Stomatal } \\
\text { index }(\%)\end{array}$ & $\begin{array}{c}\text { Stomatal } \\
\text { type }\end{array}$ & Trichome type & $\begin{array}{c}\text { No. of } \\
\text { cells }\end{array}$ & $\begin{array}{l}\text { Length } \\
\text { (O.D) }\end{array}$ \\
\hline $\begin{array}{l}\text { Trichosanthes lepiniana (Naudin) } \\
\text { Cogn. (E: Snake gourd) }\end{array}$ & 526.31 & 18.75 & Paracytic & $\begin{array}{l}\text { Branched uniseriate } \\
\text { marcoform candelabra } \\
\text { hair }\end{array}$ & $\begin{array}{l}5 \text { to } \\
\text { many }\end{array}$ & 20 \\
\hline $\begin{array}{l}\text { Trichosanthes tricuspidata } \\
\text { Loureiro (H: Mahakal, Indrayan) }\end{array}$ & 349.3 & 18.6 & Actinocytic & $\begin{array}{l}\text { Unbranched, uniseriate } \\
\text { macroform conical bend } \\
\text { hair }\end{array}$ & $4-5$ & 80 \\
\hline $\begin{array}{l}\text { Trichosanthes quinquangulata A. } \\
\text { Gray }\end{array}$ & 701.75 & 26.6 & Anomocytic & $\begin{array}{l}\text { Unbranched, uniseriate } \\
\text { macroform conical and } \\
\text { filiform capitated hair }\end{array}$ & $4-7$ & $30-70$ \\
\hline \multirow{2}{*}{$\begin{array}{l}\text { Trichosanthes dioica Roxb. } \\
\text { (E: Pointed gourd; B: Potol) }\end{array}$} & 205.4 & 10.71 & Anomocytic & $\begin{array}{l}\text { Uniseriate macroform } \\
\text { conical }\end{array}$ & $2-3$ & $30-95$ \\
\hline & 273.9 & 16 & Paracytic & Glandular hair & $4-10$ & $20-32$ \\
\hline $\begin{array}{l}\text { Trichosanthes cucumerina L. } \\
\text { (B: Chichinga) }\end{array}$ & 350.89 & 9.52 & Diacytic & $\begin{array}{l}\text { Unbranched, uniseriate } \\
\text { macroform conical hair }\end{array}$ & 3 & 40 \\
\hline $\begin{array}{l}\text { Trichosanthes wallichiana (Ser.) } \\
\text { Wt. }\end{array}$ & 174.6 & 17.27 & Diacytic & $\begin{array}{l}\text { Unbranched, uniseriate } \\
\text { macroform conical hair }\end{array}$ & 3 & $30-52$ \\
\hline
\end{tabular}

T. lepiniana trichomes have flattened bases and are distributed poorly over the adaxial surface. [P1-1: I$\mathbf{K}$. In $T$. cucumerina, trichomes are densely distributed, thin walled, irregular in shape, without flattened disk at base, slightly blunt apex. [P1-1: AD]. The trichomes of $T$. wallichiana are nonglandular, apex acute. [P1- 2: V-W]. T. tricuspidata, the trichomes are 2-3 celled with well-developed flattened disk at base, slightly curved at end with acute apex and are without cystolithic appendages. [P1-2: Q-U]. The trichomes in are glandular and non-glandular, acuminate and capitated in case of $T$. quinquangulata [P1-2: M-P]. Interestingly male macroform conical hairs of T.dioica are $2-3$ celled, with prominent flattened disk of two rows of cells and female have 4-10 celled glandular hair [P1-1: E$\mathbf{H}]$. The six species can further be classified into two groups on the basis of trichome types namely (a) those in which trichomes branched (T. lepiniana) and (b) those in which trichomes unbranched (rest of five species).

\section{Discussion}

Trichome is the most significant taxonomic features for evaluating utility of the plant specimen as it is a major tool for plant's physical defence. In studied species of Trichosanthes a wide range of trichomes are found. The glandular trichomes are exclusive character of female plant in case of Trichosanthes. Glandular hairs developed as physical defence mechanism form. If foliar micromorphology is performed on Trichosanthes dioica without bloom by presence or absence of glandular hair one can easily drag conclusion on its identity. Presently, six trichome types are recorded respectively: uniseriate macroform conical, branched uniseriate marcoform candelabra hair, uniseriate macroform conical bend hair, uniseriate macroform filiform capitated hairs. uniseriate macroform conical and glandular trichomes. Trichomes are mostly present on adaxial surface in all the studied taxa. Exclusive trichome types like filiform capitated trichomes are observed 
in T. quinquangulata. In T. tricuspidata, trichomes are Branched, uniseriate marcoform candelabra uniseriate macroform bend conical shaped. trichomes are observed only in Trichosanthes lepiniana.
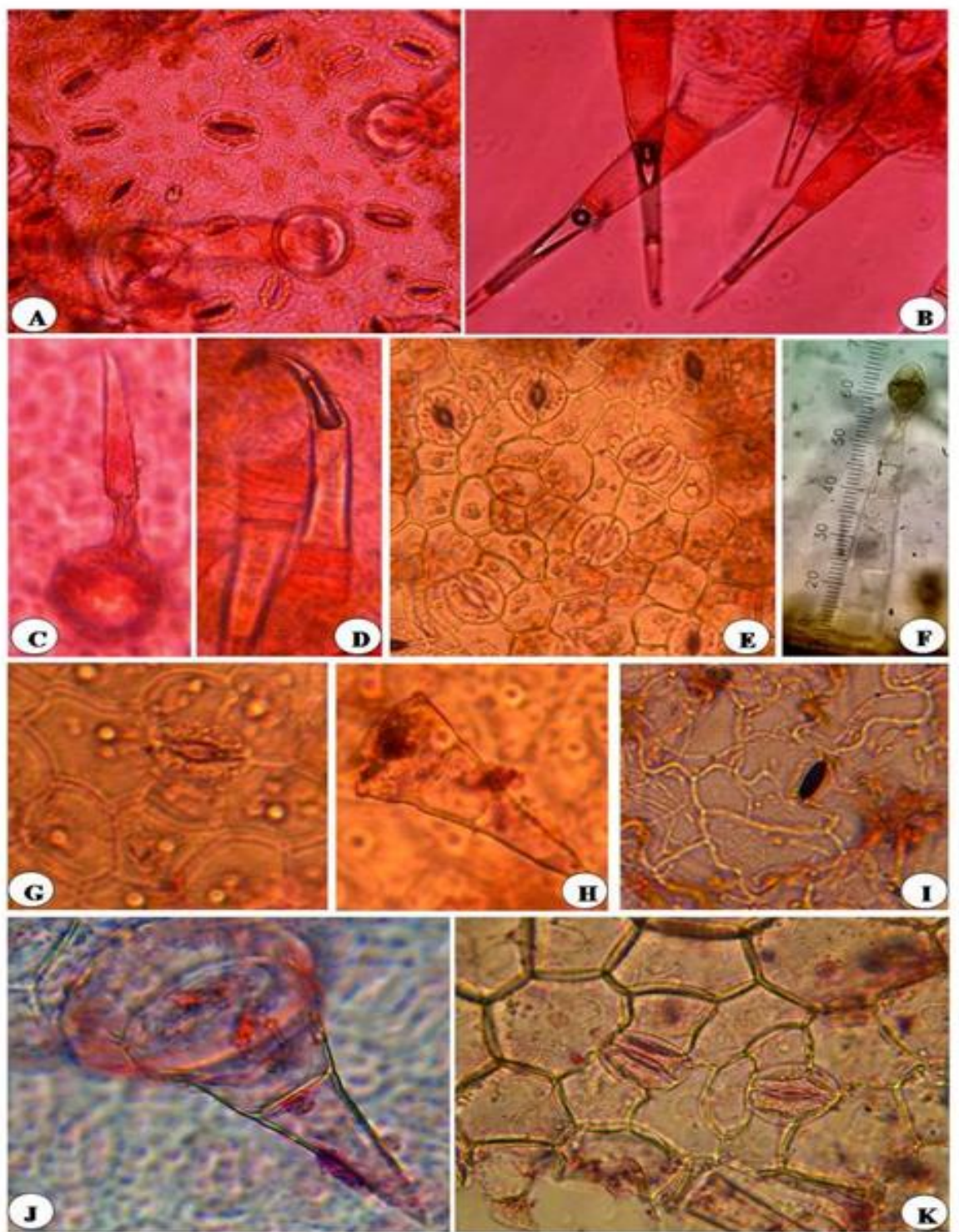

Plate 1. A \& B Abaxial stomata \& trichome C \& D Adaxial trichome of Trichosanthes cucumerina; E \& F Abaxial stomata \& trichome G \& H Adaxial stomata \& trichome of Trichosanthes dioica; I \& J Abaxial stomata \& trichome $\mathrm{K}$. Adaxial stomata of Trichosanthes lepiniana

Taxonomic significance of epidermal characters including epidermal cell architecture, such as the stomatal complex and surface ornamentation have been used in some cases as a substitute method to classify at the genus as well as species level (Sharma \& Dunn 1969; Stace 1965). On the other hand, six species categorized on the basis of stomatal structure and distribution. Three species are amphistomatic except T. lepiniana, T. wallichiana and T. cucumerina where the stomata are restricted on abaxial surface. Amphistomatic stomata are actinocytic and anomocytic whereas abaxial surface stomata are diacytic and paracytic. This amphistomatic nature is one such character which can aid to taxonomic identification and systematic classification.

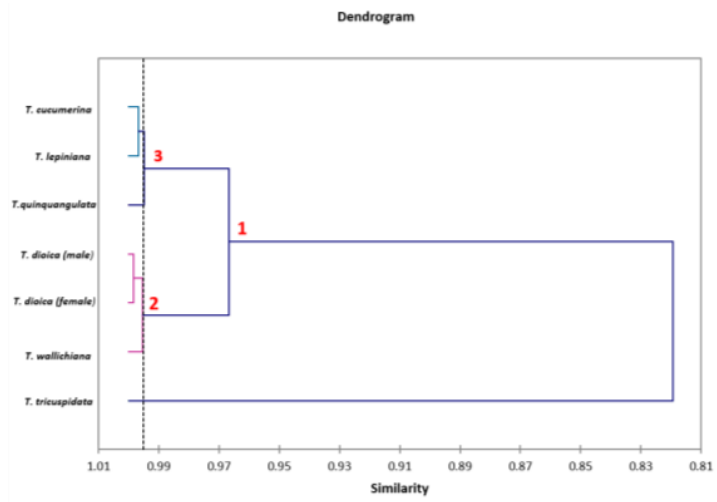

Figure 1. Dendogram of six species of Trichosanthes (male and female data of T.dioica included separately) 


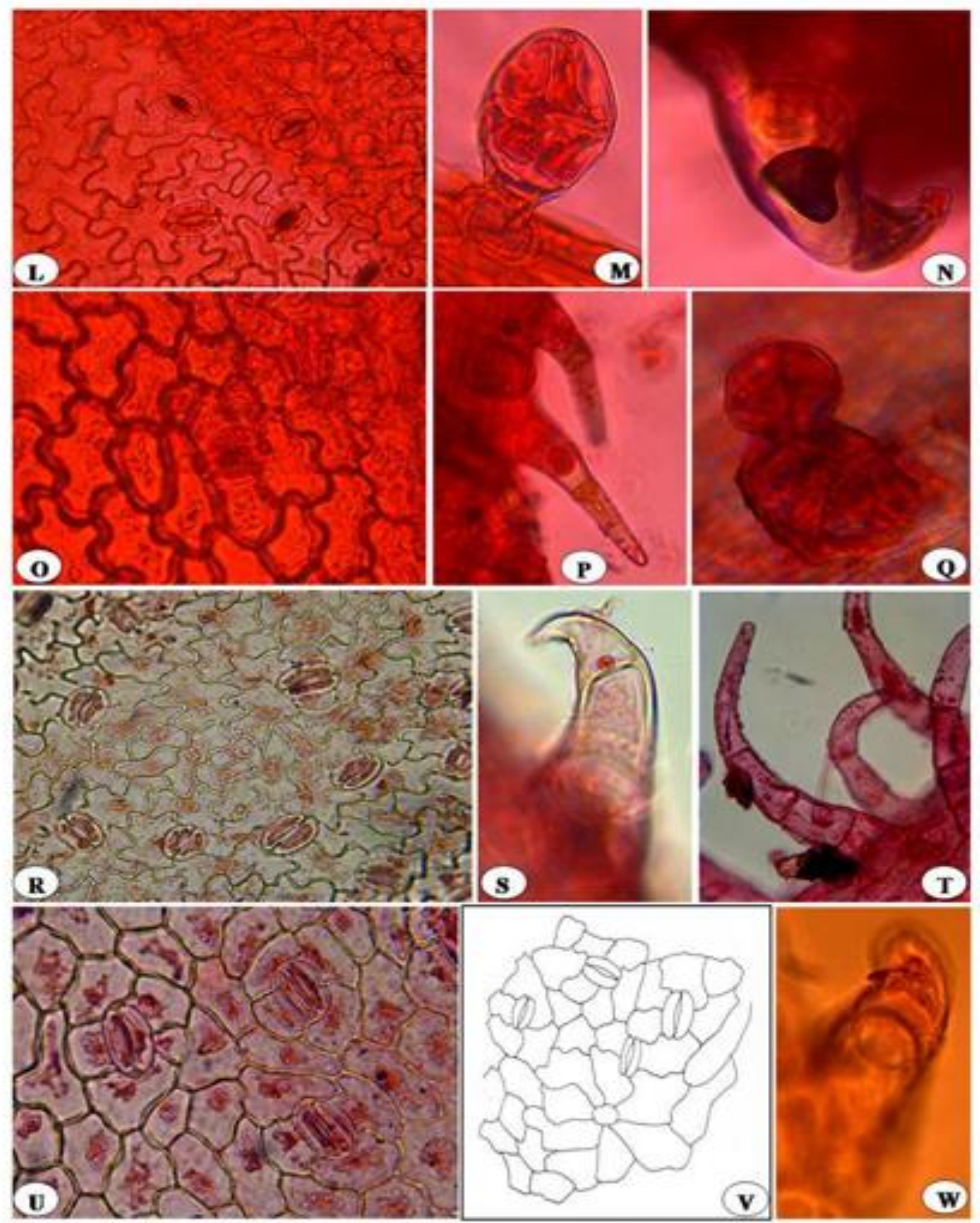

Plate 2. L Abaxial stomata M \& N Abaxial trichome $O$ \& $P$ Adaxial stomata \& trichomeT Quinqwangulata; Q \& S Abaxial trichome R Abaxial stomata T \& U Adaxial tricome \& stomata $T$. tricuspidata; V. Camera lucida drawing of abaxial stomata W Abaxial trichome of $T$ wallichiana

The diversity of foliar micro-morphological features was based on the variation of trichome types and stomata types. All of these features are very conserve for specific species and can be helpful for authentic identification of Trichosanthes species. The hierarchical clustering (Fig.1) showed three constant clustered groups based on similarity of leaf micro-morphology including stomata and trichome. The very first clad of $T$. tricuspidata bifurcates and stands odd out of even because the clustering separates $T$. tricuspidata and the remaining Trichosanthes species on other branch (1) showing the maximum dissimilarity and primitiveness from the rest. The branch 1 separates into two groups one with three species T.dioica (male and female) and $T$. wallichiana and other with three species T.lepiniana, T.cucumerina and T.quinquangulata. The three-species come off the branch that goes up from branch 1 to 2 showing more proximity. The branch 2 further splits into two lines one clad having T.dioica male and female showing highest similarity than other clad of T.wallichiana. It seems that the male and female species are developed simultaneously. The branch 3 splits into two clads 
where T.cucumerina and T.lepiniana of first clad shares more similarity than T.quinquangulata of second clad.

\section{Species key of six species of Trichosanthes}

1a. Trichomes branched, stomata paracytic T. lepiniana

1b. Trichomes unbranched, stomata non-paracytic ... 2

2a. Trichomes with glandular hairs, less than 3 celled ..................................... T. dioica

2b. Trichomes without glandular hairs, more than 3 celled

3a. Conical and filiform capitated hairs present, stomatal frequency more than $700 \mu \mathrm{m}$

..T.quinquangulata

3b. Only conical hairs present, stomatal frequency less than $700 \mu \mathrm{m}$

4a. Stomata present on both surfaces, presence of conical bend hair .................... T. tricuspidata 4b. Stomata present on single surface, absence of conical bend hair 5

5a. Stomatal index less than 10, trichome length less than 50 O.D T. cucumerina 5b. Stomatal index more than 10, trichome length more than 50 O.D T. wallichiana

\section{Conclusion}

Based on foliar micro-morphological features, species of the genus Trichosanthes can readily be distinguished from one another. Such foliar micromorphological features as on trichome and stomata are thus useful tools for diagnostic and other taxonomic works without blooms. This approach can be put to use in several disciplines of biological science and by this approach we can easily documented the micro-morphological data for further uses. The enumerated characteristics of trichomes and stomata have potential taxonomic capability for authentication of species and below rank identification and also for power drugs of medicinally important Trichosanthes and their adulterants. Not only that, phenetic studies provides great impact finder evidence on their species level affinity. The cluster analysis reveals the closest affinity within T.cucumerina and T.lepiniana; T.dioica male and T.dioica female. The separation of male and female clad hypothised parallel evolution. Whereas, T.tricuspidata shows maximum dissimilarity proving evolved as one of that alone within the other species studied.

\section{Acknowledgement}

The first author is very much thankful to the Head, Department of Botany, University of North Bengal for all possible assistance and thankful to Miss Payel Paul, Senior Research Scholar. Plant Taxonomy \& Biosystematics Laboratory, University of North Bengal for assisting in dendrogram preparation.

\section{References}

1. Abdulrahaman A.A., R.A. Oyedotun \& F.A. Oladele. "Diagnostic significance of leaf epidermal features in the family Cucurbitaceae". Insight Botany. 1(2011): 2227. Print

2. Adebooye O.C., M. Hunsche, G. Noga \& C. Lankes. "Morphology and density of trichomes and stomata of Trichosanthes cucumerina (Cucurbitaceae) as affected by leaf age and salinity". Turk J. Bot. 36(2012): 328 335

3. Ali M.A. \& M.A. Fahad. "Taxonomic significance of trichomes micro morphology in Cucurbits". Saudi J. of Biol. Sci. 18.1(2011): $87-92$.

4. Bibi J.O. \& B.E. Okoli. "Morphological, anatomical and cytological studies on Lagenaria breviflora (Benth.) Roberty (Cucurbitaceae)". International J. Life Sciences. 3.3(2014): 131-142

5. Chakravarty H.L. "Studies on Indian Cucurbitaceae with special remarks on distribution and uses of economic species".(1946); Govt. of India Press: Calcutta [Reprint of the article appearing in the Indian Journal of Agricultural Science, Vol. XVI, Part 1].

6. Chauhan D. \& M. Daniel. "Foliar Micromorphological Studies on Some Members of the Family Fabaceae". International J. of Phr and BioSci. 2.4(2011): 603-611.

7. Creedy J.A. "Laboratory Manual for Schools and Colleges". Heinemann Educational Books Ltd. (1977).

8. Dilcher D.L. "Approaches to the identification of angiosperm leaf remains”. Bot. Rev. 40(1974):1-157.

9. Esau K. “Anatomy of Seed Plants”.(1959); 2 - 324. John Wiley \& Sons, Inc. U.S.A.

10. Ibrahim G. "Microscopical studies on the leaves of Momordica charantia". Niger J Nat Prod Med. 7(2003): 44-45.

11. Inamdar J.A., M. Gangadhara \& K.N. Shenoy. "Structure ontogeny organographic distribution and taxonomic significance of trichomes and stomata in the Cucurbitaceae In: Biology and Utilization of the Cucurbitaceae", eds. Bates DM, Robinson RW and Jeffrey C, Cornell University Press, Ithaca, New York.(1990):209-224.

12. Inamdar J.A. \& M. Gangadhara. "Structure, ontogeny classification and organographic distribution of trichome in some Cucurbitaceae". Feddes Report. 86(2008): 307-320.

13. Kolb D. \& M. Muller. "Light, conventional and environment scanning electron microscopy of the trichomes of Cucurbita pepo subsp. Pepo var. styriaca and histochemistry of glandular secretory products". Ann. of Botany. 94.4(2004): 515-526. 
14. Metcalfe C.R. "Anatomy of the Dicotyledons". Oxford Clarendon Press, U.K. 2(1950): 965-978.

15. Metcalfe C.R. "Current development in systematic plant anatomy". In: Heywood V. H (Ed.) Modern methods in plant taxonomy. Academic Press, London, New York. (1968): 45-57.

16. Mitra S., S.K. Mukherjee \& S. Bandopadhyay. Cucurbitaceae of West Bengal - a census in International Seminar on "Multidisciplinary Approaches in Angiosperm Systematics. (2005): 186205.

17. Obiremi E.O. \& F.A. Oladele. "Water conserving stomatal system in selected Citrus species". S. Afr. J. Bot. 67(2001): 258-260.

18. Philips E.A. Method of vegetation study. (1959), Henry Holt and Co. Inc., New York, USA,107.

19. Rai M., S. Pandey \& S. Kumar. Cucurbit research in India: a retrospect. Proceedings of the IXth EUCARPIA meeting on genetics and breeding of cucurbitaceae (Pitrat M, ed), (2008). INRA, Avignon (France).

20. Sharma G.K \& D.B. Dunn. "Environmental modification of leaf surface traits in Datura stramonium". Can. J. Bot. 47(1969): 1211- 1216.

21. Stace C.A. "The significance of the leaf epidermis in the taxonomy of the Combretaceae: conclusions". Bot. J. L. Society. 81.4(1980): 327-339.

22. The Plant database. http://www.theplantlist.org. Accessed: 25 $5^{\text {th }}$ September 2018.

\section{Cite this article as:}

Roshni Chowdhury, Anurag Chowdhury \& Monoranjan Chowdhury. Foliar micromorphological character studies on Trichosanthes L. (Cucurbitaceae) from Terai \& Duars, West Bengal, India. Annals of Plant Sciences 7.10 (2018) pp. 2435-2440.

do http://dx.doi.org/10.21746/aps.2018.7.10.2

Source of support: University of North Bengal. Conflict of interest: Nil. 